\title{
Research on Inheritance and Development Path of Architectural Form in Style of Art Nouveau Movement in Harbin
}

\author{
Xin Ni \\ School of Design Art \\ Harbin University of Commerce \\ Harbin, China
}

\begin{abstract}
Art Nouveau" movement originates from France. This architectural style was introduced into Harbin at the beginning of last century. At that time, tsarist Russia constructed Middle East Railway in northeast China and found city by taking Harbin as transportation junction. Compared with the same style in other places of the world, the architectural style of "Art Nouveau" movement in Harbin shows sky-high developmental level no matter on art, technology and durability of time. We should develop new value of the old architectural style.
\end{abstract}

Keywords—“Art Nouveau” movement; Harbin; building; deconstruction

\section{INTRODUCTION}

Harbin is a famous city in the world for beautiful buildings. In the treasure-house of world's architectural art, there is a distinctive building form that makes Harbin find a new path in building environment of the east, winning the good reputation of "Little Paris in the Orient". It is the architectural style of "Art Nouveau" movement that originates from France and gets vigorous development in Harbin. For this kind of symbolic building form, how can today's Harbin people inherit and carry forward it? The author will discuss this problem.

\section{BASIC DEVELOPMENT History OF ART NOUVEAU MOVEMENT STYLE}

\section{A. Generation of "Art Nouveau" movement}

It is well-known that the "Art Nouveau" movement originates from France. In 1889, in order to celebrate one hundredth anniversary of the victory of the French Revolution, engineer Gustave Eiffel designed the famous Eiffel Tower as the gift for world's fair in Paris, France. It is unexpected that the landmark building spectacular in eyes of later generations was strongly against by people in Paris and art circles at that time. The incidental influence of this event is that it makes art circles in Paris stand for abandoning the existing antiquated idea, and the movement of "Art Nouveau" under the background of industrialized age is carried out vigorously.

\section{B. Development of Building Style of Art Nouveau Movement}

"Art Nouveau" movement is the largest scale of new attempt of art circles in art aiming at traditional handicraft industry moves toward large machinery industry before modernism. This movement makes great achievements, spreads over a wide range and involves many fields of art, so it is difficult for us to define it as single artistic style. As a whole, in theory, although the "Art Nouveau" movement does not surpass the artistic ideas of Ruskin, the founder of theory of arts and crafts movement, in form, it completely abandons existing old elements and thoroughly takes the road to pursuing new forms. The influence of "Art Nouveau" movement on buildings is very extensive. Through long-term practice and innovation of architects, it gradually forms architectural style of "Art Nouveau" movement that opposes copy and gather of eclecticism and pays attention to natural style, line of beauty and organic form. This architectural style is spread from south-western Europe to north of Europe. After being introduced into Moscow, it was introduced into Harbin at the beginning of the last century when tsarist Russia constructed Middle East Railway in northeast China and found city by taking Harbin as transportation junction.

\section{CHARACTERISTICS OF ARCHITECTURAL STYLE OF "ART NOUVEAU" MOVEMENT IN HARBIN}

Compared with the same style in other places of the world, the architectural style of "Art Nouveau" movement in Harbin shows sky-high developmental level on art, technology and durability of time and has the following characteristics:

Firstly, the architectural style and form of "Art Nouveau" movement in Harbin has rich resources. It follows general features of architectural style of "Art Nouveau" movement in the world, with unfolded and natural modeling, decoration method not to stick to one pattern, beautiful and fluent curve and skyscraping aesthetic value.

Secondly, the application of "Art Nouveau" movement style in Harbin is flexible and extensive. Its application is not limited to monolithic architecture and buildings of other artistic styles. Architectural elements of "Art Nouveau" movement style are often appeared local parts. 
Thirdly, the development of architectural style of "Art Nouveau" movement in Harbin is very healthy. It does not fall into the wrong region of formalism just as Europe shows in the last phase of "Art Nouveau" movement. On the contrary, because of being widely applied in urban construction, it gains plenty of experience in organically integrating decorative elements with using function of space and rapidly moves towards maturity in practice and shows vigorous vitality. At that time, architectural style of "Art Nouveau" movement was widely applied in some small independent residences and integrated in urban public construction system. Large buildings with public place such as Daoli Branch of Churin Foreign Firm, Harbin Railway Station, Russian Market (Museum of Heilongjiang Province at present) are built in "Art Nouveau" style, which cannot be found in Europe.

Fourthly, the architectural style of "Art Nouveau" movement in Harbin got full development around 1990 and in golden period of "Art Nouveau" movement in the world. Besides, the time of duration of "Art Nouveau" architectural style in Harbin is far longer than other countries in Europe. Because Harbin wasn't excessively influenced by other architecture schools and impacted by the First World War, after the "Art Nouveau" movement stopped around 1906, the "Art Nouveau" movement style in Harbin can exist until the 1930s. The platform awning in front of the door of Longmen Grand Hotel was built by Japanese in the second overhaul of the building in 1936 and it was typical steel components in Art Nouveau style. It is the most striking evidence for conservation of "Art Nouveau" movement in Harbin.

The unique artistic characteristics and great aesthetic value contained by architectural style of "Art Nouveau" movement in Harbin remain to be developed by us. Harbin people should inherit this precious architectural heritage. If people only do rigid research on this architectural style, they let down the source code left by it. We shall develop new value of this old architectural style.

\section{ANALYSIS ON INHERITANCE AND DEVELOPMENT PATH OF ARCHITECTURAL FORMS IN STYLE OF "ART NOUVEAU" MOVEMENT IN HARBIN}

In order to inherit and develop architectural forms in style of "Art Nouveau" movement in Harbin, it is necessary for us to tease thinking of work and contents.

\section{A. Collection and Sorting of Related Data}

First of all, we shall grasp the first-hand data of buildings of "Art Nouveau" movement in Harbin. It requires us to carry out a lot of field research and exploration on existing buildings and local components in style of "Art Nouveau" movement; make document research and data sorting for recorded buildings in the style of "Art Nouveau" movement. It is the basic premise to continue it. The process of this work is complex and difficult and needs more people to participate in it.

\section{B. Thinking on Inheritable Elements of Architectural Style of "Art Nouveau" Movement in Harbin}

Based on the principle of "sublation", after grasping the first-hand data, we should pay high attention to elements in architectural style of "Art Nouveau" movement in Harbin that should be inherited by us and things that we should abandon. For any architectural style, what we can learn and inherit is nothing less its using function, idea and style form.

1) Inheritance value of using function of space of "Art Nouveau" movement in Harbin: In terms of using function of space, in today's society, our requirements for using function of buildings are different from that of eighty or ninety years ago. It is difficult to meet people's requirements on using function of buildings today if we copy the original architectural style. Since it doesn't have reference value completely on using function of space, we shall boldly abandon it.

2) Heritage value of idea of "Art Nouveau" Movement in Harbin: From perspectives of idea and heritage, we cannot neglect heritage of idea of "Art Nouveau" movement. Although the intrinsic thoughts of "Art Nouveau" movement have become history, it doesn't represent that this kind of thoughts has disappeared. In order to find the continuity of this thought, we shall start from the end of "Art Nouveau" movement.

\section{- Artistic evolution after "Art Nouveau" movement}

As mentioned above, the "Art Nouveau" movement was the largest scale of exploratory movement before modernism when art circles in Europe pursued artistic innovation in the new era. After springing up for a short span of about 20 years in Europe, the movement died of various reasons such as limitation of self-development, emergence of new schools and wars. Shortly after the movement, architectural style of modernism rapidly sprung up and swept the world. Because buildings of modernism style successfully opened up the design system on the basis of function, skillfully avoided contradictions among historical context, decorative elements and industrialized mass production and conformed to the requirements of rapid rebuilding of cities after the two world wars, they were accepted by the world. However, just because of flooding of functionalism and prevail of "international wind", it made many cities in the world show similar styles. Architectural designers showed no respect for historical culture and believed simple and crude "theory of deconstruction and reconstruction" and "theory of elite determinism" and made cities rapidly fall into traffic problem and atmosphere contamination. By the end of the 1960s, urban residents and far-sighted personages in art and design circles gradually reached a consensus of anti-modernism. The mainstream ideology of art circles gradually transfers from modernism to postmodernism.

\section{- Characteristics of postmodernism era}

Today, on theory and technology, people have completely kicked over the traces of modernism and entered the new era of postmodernism. In this era, the wish of people to change current situation of reinforced concrete in cities provides impetus and premise for production of postmodern 
architectural art; burgeoning philosophical theories such as deconstruction theory, Gestalt Theory and system theory lay theoretical foundation for development of postmodern architectural art; since the third industrial revolution, the introduction of computer-assisted technology and a series of progress achieved on engineering technology accumulate practical experience for realization of postmodern architectural art.

Under this historical background, we have reason to reexamine the idea of "Art Nouveau" movement abandoned by modernism. It is not only because the innovation exploration of architects and artists in the period of "Art Nouveau" movement is the latest artistic innovation before modernism, but also because it is very similar to the things that we do today. Examination and comparison will help us to find more things.

- Relationship of ideas between "Art Nouveau" movement and postmodernism

Firstly, people face huge impact of the era on architecture and art all the time. The revolution brought by the era for art development of human is greater than the impact brought by industrial revolution on old art. At least, in architectural art, we face the impacts from network technology, computer alternative technology, nanotechnology and centralized control technique. We have the same crisis awareness with artists in the period of "Art Nouveau" movement.

Secondly, the trend of art in two revolutions is extreme non-linear. We can hardly accurately predict the trend of development of artistic form in the future. It means that our explorations on artistic form at present are tentative. It may be groundbreaking, so was the "Art Nouveau" movement in the past. Consciousness of innovation closely connects today with the past.

Thirdly, the advancement of "Art Nouveau" movement on design level makes it keep a foothold in the current era. From the perspective of technology, it is difficult for industrial technology at that time to realize curve modeling with extremely complex structure depicted by artists of architecture during the period of "Art Nouveau" movement. It can be considered as failure. But today, we haven't obstacle on technology at all. For the Holy Family Cathedral designed by Gaudi, the famous representative personage of "Art Nouveau" movement in Spain, its process of construction continues from 130 years ago up to now. Some parts with superior difficulty must rely on today's technology to complete. It shows that the architectural style of "Art Nouveau" pulls ahead at least several times on pursuit of design. It still doesn't completely disappear.

Fourthly, in terms of pursuit of aesthetic theory, the symbolic connotation abandoned, natural style, complex curve relationship and organic form of buildings pursued during the period of "Art Nouveau" movement have close relationships with unitary connotation abandoned and diversification, surface and organic form pursued by today's deconstruction. In building scheme of Zaha Hadid and Frank Gehry, representative personages of deconstruction, natural and complex curves are elements that appear most frequently; new landmark of Harbin-typical deconstructive architecture "Harbin Theater" has graceful and flowing curves, which will make artists of "Art Nouveau" buildings feel too wonderful for words. It can be asserted that although architectural aesthetic ideas in periods of postmodernism and "Art Nouveau" movement are separated by modernism, natural inheritance relationship still exists between them.

All of these fully show that there is no gap between old theories of "Art Nouveau" movement and new theories of modern architecture and even some contents have received objective development and inheritance, which lay solid foundation for our follow-on works. It also means that it will become easier for us to find new theoretical basis for architectural forms of "Art Nouveau".

3) Development value of "Art Nouveau” movement style in Harbin: From visual form elements of buildings and components, the rich aesthetic values contained by this style shall be learned and inherited by us, but it is of insignificance to simply copy it. It is also inadvisable for us to fully improve space function of new buildings and only copy the visual image of "Art Nouveau" buildings_-just as we do on Central Avenue. Apart from whether we can reach the original level by copying original style of buildings, in terms of the method, although it helps to keep overall style of the street, it will make creative spirit of the whole street even the whole city disappear and finally fall into new eclecticism. Innovation is the source power of thoughts of "Art Nouveau" movement. Harbin once was one of the cities with creative spirit in the world at that time. Innovation is the real soul of the city famous for its complicated and various architectural forms. We shall design new package for the spirit of "Art Nouveau".

What kind of way and method shall we take to carry forward aesthetic heritage of "Art Nouveau" movement? It is more than just a problem of "inheritance".

To make aesthetic elements of "Art Nouveau" movement get new motive force of development, we shall find new theoretical basis for visual form elements of old buildings. As mentioned above, in theory, we have find ideal "new housing" for buildings of Art Nouveau movement in Harbinpostmodern deconstruction theory system. If we can use the perspective of postmodern deconstruction to deconstruct and reconstruct visual form elements of buildings of "Art Nouveau" movement, we will develop a limitless future for the architectural style that will be antiquated. The design of waiting hall in Harbin West Railway Station provides classic example for us. In the future, there are more urban public spaces looking forward to the coming of new "Art Nouveau".

\section{CONCLUSION}

The inheritance and development of architectural style of Art Nouveau in Harbin is the responsibility and expectation of the new generation of building and art workers in Harbin. Here, the author puts forward the idea that depends on new theory, inherits old architectural forms and then realizes development aim. This idea is more a start than an end. It will be enriched by relying on further researches of more scholars and practical 
workers. The author appeals to more far-sighted personages to involve in the research work and make contributions for new development of new appearance of city art in Harbin.

\section{REFERENCES}

[1] History of Modern Architecture in the World, Wang Shouzhi. China Building Industry Press, 1999

[2] Art and Thought, William Fleming, Shanghai People's Fine Arts Publishing House, China, 2000

[3] Interpretation of Semiotics of "Art Nouveau” Buildings in Harbin, Liu Yanjie, master's thesis, Harbin Institute of Technology, 2008

[4] Solidified Movement-Overview on Listed Building in Harbin City, Planning Bureau in Harbin, China Building Industry Press, 2005

[5] Outposts for Western Modern Architecture to Introduce into China Discussion on Characteristics and Historical Status of Art Nouveau Buildings in Harbin, Song-Fu Liu, Journal of Architecture, 1996. 11 